\title{
ANALYTICAL METHODS FOR VANCOMYCIN DETERMINATION IN BIOLOGICAL
} FLUIDS AND IN PHARMACEUTICALS

\author{
Marta Maria Duarte Carvalho Vila, Robson Machado de Oliveira and Marcos Moisés Gonçalves \\ Curso de Farmácia, Universidade de Sorocaba, Sorocaba - SP, Brazil \\ Matthieu Tubino* \\ Instituto de Química, Universidade Estadual de Campinas, CP 6154, 13083-970 Campinas - SP, Brazil
}

Recebido em 25/8/05; aceito em 7/4/06; publicado na web em 31/10/06

\begin{abstract}
Vancomycin is a glycopeptide antibiotic employed in the treatment of infections caused by certain methicillin-resistant staphylococci. It is indicated also for patients allergic to penicillin or when there is no response to penicillins or cephalosporins. The adequate vancomycin concentration levels in blood serum lies between 5 and $10 \mathrm{mg} / \mathrm{L}$. Higher values are toxic, causing mainly nephrotoxicity and ototoxicity. Various analytical methods are described in the literature: spectrophotometric, immunologic, biologic and chromatographic methods. This paper reviews the main analytical methods for vancomycin determination in biological fluids and in pharmaceutical preparations.
\end{abstract}

Keywords: antibiotic; vancomycin; quantitative analysis.

\section{INTRODUCTION}

Vancomycin is a glycopeptide antibiotic first isolated in 1956 from Streptomyces orientalis cultures in a research developed by Laboratory Lilly, USA. It was first introduced in medical clinic in 1958.

The structure of vancomycin (Figure 1), elucidated at the end of the 70's, is tricyclic and the molecular mass was about $1500 \mathrm{Da}$. Vancomycin acts against gram-positive coccus and bacillus inhibiting the biosynthesis of the cell-wall mucopeptide, leading to a growth stalling and to the eventual destruction of the cell by lysis, in addition to which, RNA synthesis is inhibited. Vancomycin is resistant to the proteolytic enzymes activity due to its molecule complexity ${ }^{1-3}$.

The discovery of vancomycin represented, at first, an alternative for treating infections caused by the staphylococcus that produces penicilinase and the ones that are resistant to penicillin G. However, the discovery of methicillin, oxacillin and other isoxazolilpenicillins lessened the therapeutical importance of vancomycin due to its higher toxicity ${ }^{3}$.

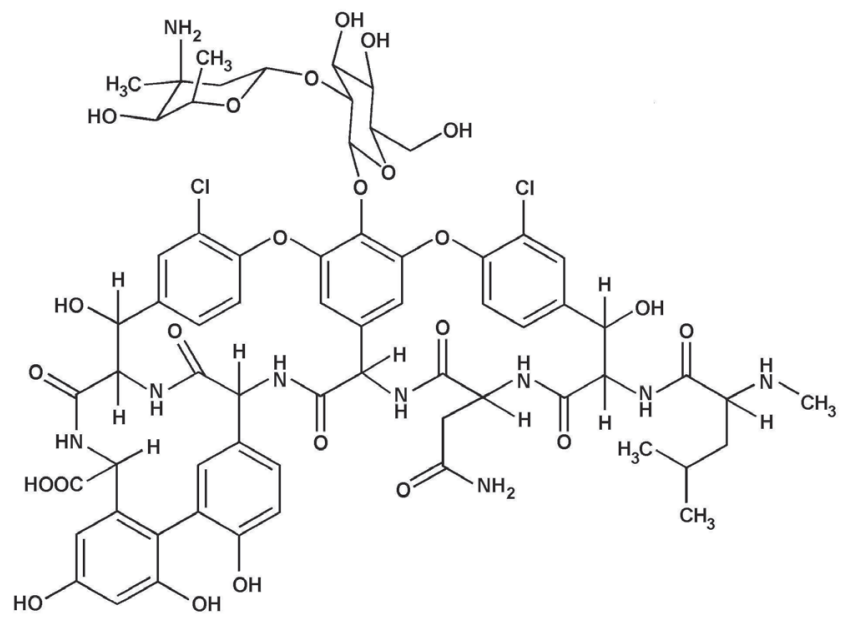

Figure 1. Structural formula of vancomycin

\footnotetext{
*e-mail: tubino@iqm.unicamp.br
}

Nowadays, however, vancomycin has emerged as an important anti-infectious agent as a consequence of the discovery of methicillin resistant staphylococcus and also due to infections caused by Clostridium difficile.

Vancomycin is very efficient against a number of gram-positive micro-organisms, including Staphylococcus aureus and Staphylococcus epidermidis. It is also the chosen antibiotic to treat bacterial infections in patients allergic to $\beta$-lactam antibiotics. Today, vancomycin resistant Staphylococcus aureus strains are a serious concern ${ }^{46}$.

Ototoxicity, that damages the auditive nerve, is the major problem caused by vancomycin treatment, as well as nephrotoxicity. The ototoxicity occurs in 2 to $5.5 \%$ of the patients, more frequently when blood concentration levels exceed $80 \mathrm{mg} \mathrm{L}^{-1}$. The nephrotoxicity is observed in 5 to $7 \%$ of the patients and is more likely to occur when the serum vancomycin concentration exceeds $10 \mathrm{mg} \mathrm{L}^{-1}$. This percentage can reach $35 \%$, if the vancomycin is associated with aminoglycoside drugs. "Red-man" syndrome, also known as "red-neck" syndrome is reported to occur in up to $47 \%$ of patients receiving vancomycin. The reaction is characterized by face, neck, and upper extremities erythematous flushing, and it is thought to be related to histamine release in response to a too-rapid infusion. Thrombophlebitis, fever, rash and neutropenia occur at lower rates ${ }^{7,8}$.

It is recommended intravenous administration. Vancomycin is not absorbed orally and intramuscular administration can provoke pain, hypersensitivity and muscular tissue necrosis. For the majority of gram-positive micro-organism treatments, the proper vancomycin seric concentration lies in a 5 to $10 \mathrm{mg} \mathrm{L}^{-1}$ range. Higher values are considered potentially toxic ${ }^{7}$ and, therefore, it is recommended to maintain the seric concentration below $40 \mathrm{mgL}^{-1}$ to avoid or, at least, reduce, the toxic effects ${ }^{9}$. However, there are several controversies when it comes to turn serum vancomicyn concentration a routine. Generally, for adults with normal renal functions, a daily monitoring is not considered necessary. Instability of vancomycin concentration in renal failure, renal support therapies, obesity, liver failure, neutropenia, malignancy and sepsis demands closer monitoring. It is also recommended for patients with altered renal function, specially for those with therapy combined with other aminoglycoside or other nephrotoxic drug; to maintain the adequate concentration for patients under renal dialysis; for those with altered distribution 
volume, i.e., with burnings; infants and newly born babies; pregnant women; patients with cancer; those who need high doses of antibiotic and instances of prolonged vancomycin treatment ${ }^{7}, 10,11$.

Therefore, it is really necessary to determinate blood vancomycin concentration, as well as in other body fluids, in order to adjust its correct dose, for better results with minor side effects. To adequately control its concentration in biological fluids, it is obviously necessary to quantitatively analyze its amounts in the pharmaceutical dosage forms.

A review of the quantitative analytical methods, described in the literature for vancomycin determination, both in biological matrixes and in pharmaceutical products, is presented below.

\section{SPECTROPHOTOMETRIC METHODS}

Fooks et al. ${ }^{12}$ developed a colorimetric method for vancomycin quantitative analysis, based on the reaction of Folin-Ciocalteau's reagent with antibiotic's phenolic groups, giving rise to a colored compound possessing the maximum absorption at $725 \mathrm{~nm}$. However, this reagent is not specific for vancomycin and it gives rise to blue color with other substances, mainly with those presenting the phenolic group ${ }^{13}$.

El-Ashry et al. ${ }^{14}$ described a determination method for some phenolic antibiotics (vancomycin, cefadroxil and amoxicillin), based on measurement of the orange-yellow species produced when these drugs are coupled with diazotized benzocaine in triethylamine medium. The stoichiometric ratio for the studied compounds was found to be $1: 1$. The method is applicable over the range of $2-18 \mu \mathrm{g}$ $\mathrm{mL}^{-1}$ for vancomycin. The formed compound absorbs at $442 \mathrm{~nm}$ and the detection limit is $0.0156 \mu \mathrm{g}$ for vancomycin.

Belal et al. ${ }^{15}$ described a method that involves a prior treatment with nitrous acid, then measuring the formed nitroso derivative, either by spectrophotometry or polarography. The calibration plot of the photometric method is linear over the range of 4-32 $\mu \mathrm{g} \mathrm{mL}^{-1}$, with minimum detectability of $2.7 \mu \mathrm{g} \mathrm{mL}^{-1}\left(1.8 \times 10^{-6} \mathrm{~mol} \mathrm{~L}^{-1}\right)$.

Three methods were proposed by Sastry et al. ${ }^{16}$, based on vancomycin oxidation with a sodium metaperiodate excess, forming colored species, after reacting with different substances. Though, with good analytical results (detection limit 1.15 to 5.11 of $\mu \mathrm{g} \mathrm{mL}^{-1}$ ), in all of those methods, it is necessary to heat the substances for about $40 \mathrm{~min}$ in a boiling water bath. However, despite the known fact that vancomycin has its degradation rate increased when heated in solution, these methods seem not to be affected by heating ${ }^{17,18}$.

Spectrophotometric analytical methods are usually of low cost and relatively easy to be performed, but probably due to the complexity of the vancomycin molecule, very few methods using such technique are described in the literature. Due to the insufficient detection limit, the related spectrophotometric procedures for vancomycin are adequate only for the analysis of medicines and not to determine antibiotics in biological fluids.

\section{IMMUNOLOGIC METHODS}

The immunologic methods employed in vancomycin quantification include the following techniques: fluorescence polarization immunoassay (FPIA), radioimmunoassay (RIA) and enzymemultiplied immunoassay (EMIT). The quantification of vancomycin using FPIA and EMIT ${ }^{19-23}$ are analytical techniques based on commercial kits or automated analyzers. These procedures offer sensitivity, sensibility, quickness, and reduced human contact with the biological samples. However, there is the disadvantage of always having to depend on the companies that hold commercial rights.

The FPIA technique has been pointed out as being the most employed one for routine analysis of vancomycin in biological samples ${ }^{7}$. Tobin et al. ${ }^{9}$ related that it was used in $97 \%$ of the hospitals investigated. The EMIT is another useful clinical assay with similar results when compared whit FPIA and HPLC ${ }^{24}$.

However, it is considered to overestimate the amount of vancomycin in blood samples, compared to FPIA and HPLC techniques. This could be a consequence, among other factors, of the interference of crystalline degradation products ${ }^{17,24-32}$.

Considering that, Abbot Laboratories developed the kit "AxSYM Vancomycin II Assay ${ }^{\hat{A}}$ ", for vancomycin quantification with FPIA. The assay demonstrates no cross-reactivity to crystalline degradation product in commonly-prescribed and over-the-counter drugs, as well as a minimum interference from endogenous substances. Linearity of the calibration curve from 1.0 to $100 \mu \mathrm{g} \mathrm{mL}^{-1}$ was observed. The variation coefficients range from about 2.9 to $4.3 \%$. The sensitivity is lower than $2.0 \mu \mathrm{g} \mathrm{mL}^{-1}$. A good correlation with other methods was observed ${ }^{22,33}$.

The RIA method ${ }^{34-37}$ had also been employed. Despite the good quality of the analytical results, it is less efficient and more expensive than FPIA, and there is also the disadvantage of using radioactive substances ${ }^{37}$.

\section{BIOLOGICAL METHODS}

Antibiotics quantification using micro-organisms can be performed by the disk diffusion technique and by turbidimetry. A linear relationship between zone diameter and concentration was obtained.

The most used method is the disk diffusion technique, that correlates the size of the zone were the growing was inhibited with the substance dose. A linear relationship between zone diameter and antibiotic concentration was obtained.

However, when the substance is chemically well defined and its quantification is possible through the physico-chemical properties, biological methods are not the first choice ${ }^{38}$. Despite the low cost, they are usually very slow and involve intense laboratorial work, when compared to other methods ${ }^{21,34}$.

In biological assays for vancomycin quantification by disk diffusion technique, Bacillus subtilis ATCC $6633^{21,34,39}$ or Bacillus subtillis W23 ${ }^{40}$ are generally employed as reference microorganisms. However, Durodie and Coleman ${ }^{41}$ presented a new technique, using Streptococcus sanguis ATCC 12396 to increase the detection range of vancomycin, that is between 1 and $16 \mathrm{mg}$ $\mathrm{mL}^{-1}$ when Bacillus subtillis is used.

When using biological methods, the analysis time may vary, depending on the procedure used: from six to eight hours at 37 ${ }^{\circ} \mathrm{C}^{21,34}$; from ten to twelve at $35-37{ }^{\circ} \mathrm{C}^{40,41}$, and from sixteen to eighteen at $35-37{ }^{\circ} \mathrm{C}^{39,42}$. Also, there is not good sensibility and reproducibility. Therefore, these methods for the quantification of vancomycin in a routine method are not used nowadays.

\section{CHROMATOGRAPHIC METHODS}

The initial chromatographic analysis of vancomycin was performed on paper and used for identification purposes ${ }^{43,44}$. For separation and identification of vancomycin thin-layer chromatography, normal and reverse phases, were used $^{45}$. Today, the HPLC is the most used technique for the vancomycin analysis, being also official method (United States Pharmacopoeia ${ }^{46}$ and British Pharmacopoeia ${ }^{47}$ ) for purity determination.

In pharmaceutical industries, the use of HPLC has been associated to the antibiotics analysis and this technology became available for quality control. In the clinical laboratory the use of this technique has been efficient for analytes determination of in several biologic fluids. Therefore, HPLC technique has been developed for the analysis of vancomycin in medicines ${ }^{48-52}$, as well as for the determination in biological fluids ${ }^{25,26,53-67}$. 
Table 1. Methods for quantification of vancomycin in biological and in pharmaceutical matrixes

\begin{tabular}{|c|c|c|c|c|}
\hline Method & Detection system & LOD & Matrices & Ref. \\
\hline HPLC & $\mathrm{UV}, \lambda=240 \mathrm{~nm}$ & $0.01 \mu \mathrm{g} \mathrm{mL}^{-1}$ & Human plasma & 55 \\
\hline HPLC & Tanden mass spectrometry & $1.0 \mathrm{ng} \mathrm{mL}^{-1}$ & Dog, rat and primate serum and urine & 66 \\
\hline HPLC & Tandem mass spectrometry & $0.007 \mu \mathrm{g} \mathrm{mL}^{-1}$ & Rat plasma & 65 \\
\hline HPLC & $\mathrm{UV}, \lambda=235 \mathrm{~nm}$ & - & Human serum & 25 \\
\hline HPLC & Electrochemical & $0.5 \mu \mathrm{g} \mathrm{mL}^{-1}$ & Human plasma & 62 \\
\hline HPLC & $\mathrm{UV}, \lambda=282 \mathrm{~nm}$ & $0.5 \mu \mathrm{g} \mathrm{mL}^{-1}$ & Human plasma and tissues & 60 \\
\hline HPLC & $\mathrm{UV}, \lambda=214 \mathrm{~nm}$ & $100 \mathrm{ng} \mathrm{mL}^{-1}$ & $\begin{array}{l}\text { Human serum, cerebrospinal } \\
\text { fluid and peritoneal fluid }\end{array}$ & 53 \\
\hline HPLC & $\mathrm{UV}, \lambda=230 \mathrm{~nm}$ & - & Pharmaceuticals forms & 52 \\
\hline HPLC & $\mathrm{UV}, \lambda=225 \mathrm{~nm}$ & $0.32 \mu \mathrm{g} \mathrm{mL}^{-1}$ & Human serum and plasma & 57 \\
\hline HPLC & $\mathrm{UV}, \lambda=198 \mathrm{~nm}$ & $0.03 \mu \mathrm{g} \mathrm{mL}^{-1}$ & Rabbit serum, vitreous and aqueous humor & 59 \\
\hline HPLC & $\mathrm{UV}, \lambda=240 \mathrm{~nm}$ & $0.4 \mu \mathrm{g} \mathrm{mL}^{-1}$ & Microdiaysate and human plasma & 67 \\
\hline HPLC & $\mathrm{UV}, \lambda=230 \mathrm{~nm}$ & $30.0 \mathrm{ng} \mathrm{mL}^{-1}$ & Influenza vaccine & 50 \\
\hline HPLC & $\mathrm{UV}, \lambda=230 \mathrm{~nm}$ & $0.5 \mu \mathrm{g} \mathrm{mL}^{-1}$ & Human plasma & 63 \\
\hline HPLC & $\mathrm{UV}, \lambda=225 \mathrm{~nm}$ & - & Antibiotics mixture & 48 \\
\hline HPLC & $\mathrm{UV}, \lambda=254 \mathrm{~nm}$ & - & Vancomycin mixtures and related substances & 49 \\
\hline HPLC & $\mathrm{UV}, \lambda=228 \mathrm{~nm}$ & $1.0 \mu \mathrm{g} \mathrm{mL}^{-1}$ & Human serum & 56 \\
\hline HPLC & $\mathrm{UV}, \lambda=229 \mathrm{~nm}$ & $1.0 \mu \mathrm{g} \mathrm{mL}^{-1}$ & Human serum and tissues & 54 \\
\hline HPLC & $\mathrm{UV}, \lambda=229 \mathrm{~nm}$ & $0.2 \mu \mathrm{g} \mathrm{mL}^{-1}$ & Human plasma & 58 \\
\hline HPLC & $\mathrm{UV}, \lambda=280 \mathrm{~nm}$ & - & Pharmaceuticals forms and impurities & 51 \\
\hline HPLC & $\mathrm{UV}, \lambda=230 \mathrm{~nm}$ & $0.8 \mu \mathrm{g} \mathrm{mL}^{-1}$ & Human plasma & 61 \\
\hline HPLC & $\mathrm{UV}, \lambda=215 \mathrm{~nm}$ & $0.5 \mathrm{~m} \mu \mathrm{g} \mathrm{mL} \mathrm{m}^{-1}$ & Human plasma & 64 \\
\hline HPLC & $\mathrm{UV}, \lambda=280 \mathrm{~nm}$ & - & Human plasma & 26 \\
\hline Spectrophotometric & $\mathrm{UV}, \lambda=725 \mathrm{~nm}$ & - & Pharmaceuticals forms & 12 \\
\hline Spectrophotometric & $\mathrm{UV}, \lambda=725 \mathrm{~nm}$ & $0.0156 \mu \mathrm{g} \mathrm{mL}^{-1}$ & Pharmaceuticals forms & 14 \\
\hline Polarography & $\begin{array}{l}\text { Electrode graphite } \\
\text { rod and } \mathrm{Ag} / \mathrm{AgCl}\end{array}$ & $2.4^{\prime} 10^{-2} \mathrm{molL}^{-1}$ & Pharmaceuticals forms & 15 \\
\hline Spectrophotometric & $\mathrm{UV}, \lambda=240 \mathrm{~nm}$ & $2.7 \mu \mathrm{g} \mathrm{mL}^{-1}$ & Pharmaceuticals forms & 15 \\
\hline Spectrophotometric & $\mathrm{UV}, \lambda=620 \mathrm{~nm}$ & $1.15 \times 10^{-2} \mu \mathrm{g} \mathrm{mL}^{-1}$ & Pharmaceuticals forms & 16 \\
\hline Spectrophotometric & $\mathrm{UV}, \lambda=520 \mathrm{~nm}$ & $5.0 \times 10^{-2} \mu \mathrm{g} \mathrm{mL}^{-1}$ & Pharmaceuticals forms & 16 \\
\hline Spectrophotometric & $\mathrm{UV}, \lambda=5400 \mathrm{~nm}$ & $5.0 \times 10^{-2} \mu \mathrm{g} \mathrm{mL}^{-1}$ & Pharmaceuticals forms & 16 \\
\hline $\begin{array}{l}\text { Capillary } \\
\text { electrophoresis }\end{array}$ & $\begin{array}{l}\text { Laser-induced } \\
\text { fluorescence }\end{array}$ & $1.0 \mu \mathrm{g} \mathrm{mL}^{-1}$ & Human plasma & 68 \\
\hline FIA & Amperometric & - & Pharmaceuticals forms & 69 \\
\hline $\begin{array}{l}\text { Capillary } \\
\text { electrophoresis }\end{array}$ & $\begin{array}{l}\text { Laser-induced } \\
\text { fluorescence }\end{array}$ & $0.98 \mathrm{ng} \mathrm{mL}^{-1}$ & Human plasma & 71 \\
\hline $\begin{array}{l}\text { Mass spectrometry with } \\
\text { pyrolysis inlet system }\end{array}$ & & $1.0 \mathrm{ng} \mathrm{mL}^{-1}$ & Human serum & 70 \\
\hline Disk diffusion 35 & Bacillus subtilis & $<0.8 \mu \mathrm{g} \mathrm{mL}^{-1}$ & Human serum & 40 \\
\hline${ }^{\circ} \mathrm{C} / 10-12 \mathrm{~h}$ & $W 23$ & & & \\
\hline Disk diffusion37 & Bacillus subtilis & - & Human serum & 42 \\
\hline${ }^{\circ} \mathrm{C} / 18 \mathrm{~h}$ & ATCC6633 & & & \\
\hline Disk diffusion 35 & Streptococcus sanguis & $0.25 \mathrm{mg} \mathrm{L}^{-1}$ & Human serum & 41 \\
\hline${ }^{\circ} \mathrm{C} / 12 \mathrm{~h}$ & ATCC12396 & & & \\
\hline Disk diffusion35 & Bacillus subtilis & $\leq 25 \mu \mathrm{g} \mathrm{mL}^{-1}$ & Human serum & 39 \\
\hline${ }^{\circ} \mathrm{C} / 16-18 \mathrm{~h}$ & ATCC6633 & & & \\
\hline Disk diffusion37 & Bacillus subtilis & -- & Human serum & 21 \\
\hline${ }^{\circ} \mathrm{C} / 6 \mathrm{~h}$ & ATCC6633 & & & \\
\hline Disk diffusion37 & Bacillus subtilis & - & Human serum & 34 \\
\hline${ }^{\circ} \mathrm{C} / 8 \mathrm{~h}$ & ATCC6633 & & & \\
\hline RIA & Scintillation counter, $\gamma$-rays & - & Human serum & 34 \\
\hline RIA & Scintillation counter, $\gamma$-rays & $0.5 \mu \mathrm{g} \mathrm{mL}^{-1}$ & Human serum & 36 \\
\hline RIA & Scintillation counter, $\gamma$-rays & - & Human serum & 37 \\
\hline RIA & scintillation counter, $\gamma$-rays & $0.8 \mu \mathrm{g} \mathrm{mL}^{-1}$ & Human serum and urine & 35 \\
\hline EMIT & $\mathrm{UV}, \lambda=340 \mathrm{~nm}$ & - & Human serum & 19 \\
\hline EMIT & UV & -- & Human serum & 20 \\
\hline FPIA & UV,fluorescence & - & Human serum & 21 \\
\hline FPIA & UV,fluorescence & - & Human serum & 22 \\
\hline FPIA & UV,fluorescence & - & Human serum & 23 \\
\hline FPIA & UV,fluorescence & $<2.0 \mu \mathrm{g} \mathrm{mL}^{-1}$ & Human serum & 33 \\
\hline
\end{tabular}

RIA - Radioimmunoassay; EMIT - Enzyme multiplied immunoassay technique; FPIA - Fluorescence polarization immunoassay; FIA Flow injection analysis; HPLC - High performance liquid chromatography. 
Generally, it was observed that the majority of the applied methods in the determination of vancomycin with HPLC use UV detectors, working in a wavelength range from $198 \mathrm{~nm}^{59}$ to 282 $\mathrm{nm}^{60}$. Few works employ other kind of detectors, for example, Favetta et al..$^{62}$ use an electrochemical detector and Shibata et al. ${ }^{65}$ employ mass spectrometry for the detection.

It can be also noted that the use of a $\mathrm{C}_{18}$ column is the most common option, associated with a variety of mobile phases. When the HPLC technique is used for the determination of vancomycin in biological fluids, the extraction procedure of the analyte is done based on chemical processes, involving protein precipitation and use of organic solvents. In some methods, however, the extraction process is associated to the chromatography as continuous systems ${ }^{56,59,66}$. Recently analytical techniques, where the samples are injected without treatment, have been developed. Kitahashi and Furuta ${ }^{68}$ developed an assay for measuring vancomycin concentration by micellar electrokinetic capillary chromatography with detection at $210 \mathrm{~nm}$ using direct serum injection. The migration time of vancomycin was about 7 minutes. The linearity was from 0 to $100 \mu \mathrm{g} \mathrm{mL}^{-1}$ and the limit of detection was $1.0 \mu \mathrm{g} \mathrm{mL}^{-1}$. No observed interference from 32 other antibiotics was observed.

Shibata et al. ${ }^{65}$ described a novel high-performance liquid chromatography tandem mass spectrometry method for determination of vancomycin in serum and urine without treatment. After the addition of internal standard, serum and urine samples were directly injected into a HPLC system consisting of an extraction column and dual analytical columns. The columns are connected through two switching valves.

\section{OTHER METHODS}

Chabenat et al. ${ }^{69}$ proposed the use of the complex formed between copper(II) and vancomycin for the determination of this antibiotic, in continuous flux and amperometric detection.

Mass spectrometry coupled with a pyrolysis inlet system was compared with HPLC for vancomycin determination and its crystal degradation products in human serum. Quantitative analysis was performed by selected ion monitoring method at 108 mass/charge $(\mathrm{m} / \mathrm{z})$ of the pyrolysis product of vancomycin. The detection limit of the method was $1 \mathrm{ng} \mathrm{mL}^{-1}$; the linearity was observed between $1 \mathrm{ng}$ $\mathrm{mL}^{-1}$ and $10 \mathrm{mg} \mathrm{mL}^{-1}$; the relative standard deviation was $1 \%$; the time of analysis was $30 \mathrm{~min}$ and sample volume $50 \mu \mathrm{L}$. These results are far better than those of the HPLC method. However the authors related that the HPLC method can individually determine the concentration of vancomycin and its degradation products ${ }^{70}$.

A competitive immunoassay using capillary electrophoresis with laser-induced fluorescence for vancomycin was developed. Capillary electrophoresis using a tris-glycine running buffer provided adequate separation of antibody-bound from the unbound fluorescent probe (tracer) in less than $4 \mathrm{~min}$. Laser-inducedfluorescence polarization provided high sensibility detection and simultaneous monitoring of fluorescence intensity and polarization. A fluorescence polarization value of 0.30 confirmed the formation of the antibody-tracer complex. Calibration curves showed a working linear range of 2-3 orders of magnitude with a minimum detectable concentration of $0.98 \mathrm{ng} \mathrm{mL}^{-1} 71$.

\section{CONCLUSION}

As usual in quantitative analysis, the choice of the analytical method to be employed for the vancomycin analysis will be always dependent of several parameters that must be considered in each case: the analytical matrix; the sample and aliquot sizes; reagents, apparatus and trained personnel available; cost of the analysis; precision and accuracy; time required for the complete analytical procedure.

Table 1 presents a summary of suggested methods in the analytical literature for the quantitative analysis of vancomycin in several matrices. It can be easily observed that HPLC is the preferred method either for the analysis in biological or pharmaceutical material. However, for the routine analysis in hospitals, in serum or plasma, immunologic methods are the most used ${ }^{7.9}$. Despite these methods present a relatively high cost and possible interferences, they allow rapid results, exempt pre treatment of the samples and are processed with automatic apparatus. Comparing HPLC methods with the immunologic, it is observed that the former presents better accuracy and precision but higher analytical delay and involve pre extraction of the analyte. To avoid the necessity of the pre treatment some HPLC with direct injection, using pre extraction columns, have been suggested ${ }^{54,66}$.

Biological assays are also used for vancomycin quantification, inclusive in the last edition of the United States Pharmacopoeia ${ }^{47}$. However they are not used for routine analysis if biological fluids or medicines as they are slow, involve much laboratory work, present low precision and accuracy and are non specific. In the case of patients treated with more than one antibiotic the results can be seriously affected.

HPLC have been also used for the analysis of medicines, presenting detection limits as low as $1 \mathrm{ng} \mathrm{mL}^{-1}$. Spectrophotometric detectors are the more frequently used despite the fact that the more sensitive methods are those using mass detectors ${ }^{65.66}$.

The high specificity of the HPLC procedures allows the analysis of vancomycin in presence of other substances in automated systems, characteristics that justify the intense use of this technique in the analysis of this antibiotic as it was also indicated, in a recent article, by Görög ${ }^{72}$.

The relatively recent use of capillary electrophoresis has been observed. The results obtained with this technique are similar to those obtained with HPLC but with lower cost.

The spectrophotometric methods are also used mainly due to the low cost and operational simplicity. In the case of pharmaceutical analysis the detection limits are comparable to those obtained with HPLC. Their main disadvantage is the usual low specificity in presence of similar chromophoric systems as those of the drug material.

Due to the complexity of the vancomicyn molecule and its size, its quantitative analysis in biological matrixes and even in pharmaceutical products can't be considered a simple and cheap matter. In our point of view, in face of the therapeutic importance of this antibiotic and, of its toxic level, the development of new reliable methods for vancomycin analysis, in various matrixes, must be rapid and simple and, if possible, with low cost is necessary. Efforts must be done in this direction. This opinion is reinforced if it is remembered that, in a great part of the world, the financial sources destined to the public health are so small that even for the antibiotic acquisitions they are not always sufficient. Imagine how difficult it is to use analytical and necessary procedures that demand expensive devices and extremely specialized professionals.

\section{REFERENCES}

1. Willian, D. H.; Kalman, J. R.; J. Am. Chem. Soc. 1976, 99, 2768.

2. Sheldrick, G. M.; Jones, P. G.; Kennard, O.; Willians, D. H.; Smith G. A.; Nature 1978, 271, 223.

3. Tavares, W.; Manual de antibióticos e quimioterápicos, $3^{\mathrm{a}}$ ed., Atheneu: São Paulo, 2002.

4. Srinivasan, A.; Dick, J. D.; Perl, T. M.; Clin. Microb. Reviews 2002, 15, 430.

5. Menichetti, F.; Clin. Microbiol. Infection 2005, 11, 22.

6. Woodford, N.; Clin. Microbiol. Infection 2005, 11, 2.

7. Hammett-Stabler, C. A.; Johns, T.; Clin. Chem. 1998, 44, 1129.

8. Davani, S.; Muret, P.; Royer, B.; Hoen, B.; Kantelip, J. P.; Ann. Biol. Clin. 2002, 60, 655. 
9. Tobin, C. M.; Darville, J. M.; Thomson, A. H.; Sweeney, G.; Wilson, J. F.; Macgowan A. P.; White, L.O.; J. Antimicrob. Chemother. 2002, 50, 713.

10. Freeman, C. D.; Quintiliani, R.; Nightingale, C. H.; The Ann. Pharmacother. 1993, 27, 594.

11. Begg, J. E.; Barclay, M. L.; Kirkpatrick, C. M. J.; J. Clin. Pharmacol. 2001, 52,355 .

12. Fooks, R. J.; McGilveray, I. J.; Strickland, R. D.; J. Pharm. Sci. 1968, 57, 315.

13. Rao, G. R.; Kanjilal, G.; Mohan, K. R.; Analyst 1978, 103, 993.

14. El-Ashry, S. M.; Belal, F.; El-Kerdawy, M. M.; Elwasseef, D. R.; Mikrochim. Acta 2000, 135, 191.

15. Belal, F.; El-Ashry, S. M; El-kerdawy, M. M.; El-Wasseef, D. E.; Arzneim. Forsch. 2001, 51, 763.

16. Sastry, C. S. P.; Rao, T. S.; Rao, P. S. N. H. ; Prassa, U. V.; Mikrochim. Acta 2002, 140, 109.

17. White, L. O.; Edwards, R.; Holt, H. A.; Lovering, A. M.; Finch, R. G.; Reeves, D. S.; J. Antimicrob. Chemother. 1988, 22, 739.

18. Antipas, A.; Velder, D. V.; Stella, V. J.; Int. J. Pharm. 1994, 109, 261.

19. Anne, L.; Hammad, N.; Chang, C. C.; Laungani, D.; Gottwald, K.; Alexander, S.; Centofanti, J.; Clin. Chem. 1988, 34, 1256.

20. Yeo, K.; Traverse, W.; Horowitz, G. L.; Clin. Chem. 1988, 34, 1257.

21. Pohlod, D. J.; Saravolatz, L. D.; Somerville, M. M.; J. Clin. Microbiol. 1984, 20, 159 .

22. Azzazy, H. M. E.; Chou, P. P.; Tsushima, J. H.; Troxil, S.; Gordon, M.; Avers, R. J.; Chiappetta, E.; Duh, S.; Christenson, R. H.; Ther. Drug Monit. 1988 $20,202$.

23. Hermida, J.; Zaera, S.; Tutor, J. C.; Ther. Drug Monit. 2001, 23, 725.

24. Ristuccia, P. A.; Ristuccia, A. M.; Bidanset, J. H.; Cunha, B. A.; Ther. Drug Monit. 1984, 6, 238.

25. Hu, M. W.; Anne, L.; Forni, T.; Gottwald, K.; Ther. Drug Monit. 1990, 12, 562.

26. Najjar, T.; Al-Dhuwailie, A. A.; Tekle, A.; J. Chromatogr., B: Anal. Technol. Biomed. Life Sci. 1995, 672, 295.

27. Morishige, H.; Shuto, H.; Ieiri, I.; Otsubo, K.; Oishi, R.; Ther. Drug Monit. 1996, $18,80$.

28. Peckamn, H.; Dupuis, R. E.; Sawyer, W. T.; Brower, K. L. R.; Cross, S, R. E.; Ther. Drug Monit. 1996, 18, 647.

29. Bowhay, S.; Timms, P.; Ther. Drug Monit. 1997, 19, 117.

30. Paap, C. M.; Sharpe, G. L.; Dev. Pharmacol Ther. 1993, $20,174$.

31. Zaera. S.; Hermida, J.; Tutor, C.; Ther. Drug Monit. 2002, 24, 696.

32. Iwamoto, T.; Kagawa, Y.; Kojima, M.; Ther. Drug Monit. 2005, $27,56$.

33. Adamczyk, M.; Brate, E. M.; Chiappetta, E. G.; Ginsburg S.; Hoffman, E.; Klein, C.; Perkowitz, M. M.; Rege, S. D.; Chou, P. P.; Constantino, A. G.; Ther. Drug Monit. 1998, 20, 191.

34. Crossley, K. B.; Rotschafer, J. C.; Chern, M. M.; Mead, K. E.; Zaske, D. E.; Antimicrob. Agents Chemother. 1980, 17, 654

35. Fong, K. L.; Ho, D. W.; Bogerd, L.; Antimicrob. Agents Chemother. 1981, 19, 139.

36. Blouin, R. A.; Bauer, L. A.; Miller, D. D.; Rercord, K. E.; Griffen, W.; Antimicrob. Agents Chemother. 1982, 21, 575.

37. Ackerman, B. H.; Berg, H. G.; Strate, R. G.; Rostschafer, J. C.; J. Clin. Microbiol. 1983, 18, 994

38. Pinto, T. J. A.; Kaneko, T. M.; Ohara, M. T.; Controle biológico de produtos farmacêuticos, correlatos e cosméticos, $2^{\mathrm{a}}$ ed., Atheneu: São Paulo, 2004
39. Walker, C. N.; Antimicrob. Agents Chemother. 1980, 17, 730.

40. Walker, C. N.; Kopp, B.; Antimicrob. Agents Chemother. 1978, 13, 30.

41. Durodie, J. ; Coleman, K.; J. Antimicrob. Chemother. 1992, $29,347$.

42. Kureishi, A.; Jewesson, P. J.; Bartlett, K. H.; Cole, C. D.; Chow, A.W.; Antimicrob. Agents Chemother. 1990, 34, 1642

43. Betina, V.; J. Chromatogr. 1963, 15, 379 .

44. Bristish Pharmacopeia; General Medical Council: London, 1963, p. 869.

45. Nowakowska, J.; Halkieewicz, J.; Lukasiak, J. W.; Chromatographia 2002, $56,367$.

46. Bristish Pharmacopeia; Bristish Pharmacopeia Commission: London, 2002, vol. 1.

47. The United State Pharmacopeia; The National Formulary, $25^{\text {td }}$ ed., United States Pharmacopeial Convention: Rockville, 2005.

48. Kirchmeier, R. L.; Upton, R. P.; Anal. Chem. 1978, 50, 349

49. Inman, E. ; J. Chromatogr. 1987, 410, 363.

50. Forlay-Frick, P.; Nagy, Z. B.; Fekete, J.; Kettrup, A.; Gebefugi, I.; J. Liq. Chromatogr. Relat. Technol. 2001, 24, 497.

51. Diana, J.; Visky, D.; Roets, E.; Hoogmartens, J.; J. Chromatogr., A 2003, 996, 115.

52. Forlay- Frick, P.; Fekete, J.; J. Liq. Chromatogr. Relat. Technol. 2004, 27, 123.

53. Jehl, F.; Gallion, C.; Thierry, R. C.; Monteil, H.; Antimicrob. Agents Chemother. 1985, 27, 503 .

54. Bauchet, J.; Pussard, E.; Garaud, J. J.; J. Chromatogr. 1987, 414, 472.

55. Hosotsubo, H. ; J. Chromatogr., B: Anal. Technol. Biomed. Life Sci. 1989, 487, 421.

56. Demotes-Mainard, F.; Labat, L.; Vinçon, G.; Bainnwarth, B.; Ther. Drug Monit. 1994, 16, 293.

57. Li, L.; Miles, M. V.; Hall, W.; Carson, S.; Ther. Drug Monit. 1995, 17, 366.

58. Luksa, J.; Marusic, A.; J. Chromatogr. B: Anal. Technol. Biomed. Life Sci. 1995, 667, 227.

59. Del Nozal, M. J.; Bernal, J. L; Pampliega, A.; Marinero, P.; López, M. I.; Coco, R.; J. Chromatogr., A 1996, 727, 231.

60. Farin, D.; Piva, G. A.; Gozlan, I.; Kitzes-Cohen, R.; J. Pharm. Biomed. Anal. 1990, 18, 367.

61. Belli, C. V.; Dissertação de Mestrado, Universidade de São Paulo, Brasil, 2000.

62. Favetta, P.; Guiton, J.; Bleyzac, N.; Dufresne, C.; Bureau, J.; J. Chromatogr. B: Anal. Technol. Biomed. Life Sci. 2001, 751, 377.

63. Santos, C. R.; Feferbaum, R.; Paula, M. L. S. A.; Bertoline, M. A.; Omosako, C. E. K.; Santos, S. R. C. J.; Rev. Bras. Ciências Farmac. 2001, 37, 87.

64. Saito, M.; Santa, T.; Tsunoda, M.; Hamamoto, H.; Usui, N.; Biomed. Cromatogr. 2004, 18, 735 .

65. Shibata, N.; Ishida, M.; Prasad, Y. V. R.; Gao, W.; Yoshikawa, Y.; Takada, K.; J. Chromatogr., B: Anal. Technol. Biomed. Life Sci. 2003, 789, 211.

66. Cass, T. R.; Villa, J. S.; Karr, D.E.; Schmidt Jr, D. E.; Rapid Commun. Mass Spectrom. 2001, 15, 406.

67. Plock, N.; Buerger, C.; Kloft, C.; Biomed. Chromatogr. 2005, 19, 237.

68. Kitahashi, T.; Furuta, I.; Clin. Chim. Acta 2001, 312, 221.

69. Chabenat, C.; Andre, D.; Boucly, P.; Talanta 1983, 30, 963.

70. Ghassempour, A.; Darbandi, M. K.; Asghari, F. S.; Talanta 2001, 55, 573.

71. Lam, M. T.; Le, X. C.; Analyst 2002, 127, 1633.

72. Görög, S. J. Pharm. Biomed. Anal. 2005, 5, 931 